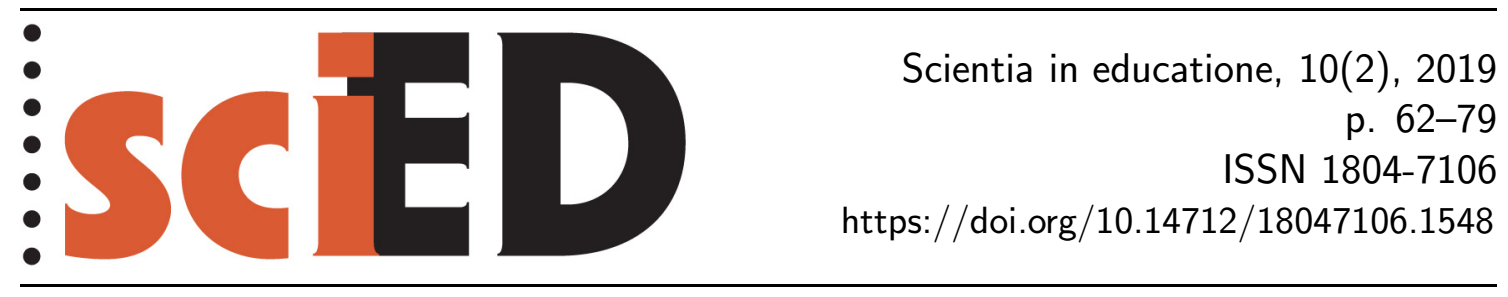

\title{
Investigating Subject Matter Knowledge and Pedagogical Content Knowledge in Mathematics with the Concept Cartoons Method
}

\author{
Libuše Samková
}

\begin{abstract}
The article focuses on an educational tool called Concept Cartoons and its possible use in professional preparation of future primary school teachers. In particular, it presents the method of how Concept Cartoons can be employed as a tool for diagnosing subject matter knowledge and pedagogical content knowledge in mathematics. The first part of the contribution introduces the concept of teachers' knowledge that is used in the article, and the Concept Cartoon tool. It describes the original Concept Cartoons method for classroom use at primary and secondary school levels that was established by Keogh and Naylor, and then it introduces our work on diagnostic Concept Cartoons method, including a commented summary of our recent research on qualitative diagnosis of subject matter knowledge and pedagogical content knowledge in mathematics. The second part of the contribution introduces another step in the methodology, a mixed approach to the issue that enables to enrich the qualitative results with quantitative characteristics. The mixed method is illustrated through a small empirical study that shows how exactly the quantitative enrichment might be provided.
\end{abstract}

Key words: Concept Cartoons, mathematics education, pedagogical content knowledge, future primary school teachers, subject matter knowledge.

\section{Zkoumání znalostí obsahu a didaktických znalostí obsahu v matematice metodou Concept Cartoons}

\begin{abstract}
Abstrakt
Tento článek se věnuje vzdělávací pomůcce Concept Cartoons a možnostem jejího využití v profesionální př́pravě budoucích učitelů 1. stupně základní školy. Konkrétně představuje metodu, jak Concept Cartoons mohou být použity jako nástroj pro diagnostiku znalostí obsahu a didaktických znalostí obsahu v matematice. První část příspěvku se věnuje teoretickému rámci (didaktických) znalostí obsahu a vzdělávací pomůcce Concept Cartoons jako takové. Popisuje původní metodu pro použití pomůcky při výuce na základní škole ustanovenou Keoghovou a Naylorem, a potom představuje naši práci na diagnostické metodě Concept Cartoons, včetně komentovaného souhrnu našeho dosavadního
\end{abstract}


výzkumu v oblasti kvalitativní diagnostiky (didaktických) znalostí obsahu v matematice. Druhá část příspěvku představuje další krok v metodologii: smíšený přistup k dané problematice, který umožňuje obohatit kvalitativní výsledky o kvantitativní charakteristiky. Smíšená metoda je názorně předvedena na malé empirické studii, která poskytuje náhled na možnou konkrétní podobu onoho kvantitativního obohacení.

Klíčová slova: budoucí učitelé 1. stupně ZŠ, Concept Cartoons, didaktické znalosti obsahu, matematické vzdělávání, znalosti obsahu.

This article is primarily intended for teachers' and future teachers' educators, but it may also serve successfully for in-service teachers. The contribution is located in a mathematics environment; however, we believe that it can be effortlessly transformed to the environment of any other school subject. It touches issues that are actual at any time: subject matter knowledge (of pupils as well as future teachers or teachers) and pedagogical content knowledge (of future teachers and teachers).

Future teachers' educators often find themselves in situations where subject matter knowledge or pedagogical content knowledge of their learners is involved and an instrument for diagnosing these kinds of knowledge would be helpful. Especially when the cooperation among teachers' educators and their learners is on long-term basis, the teachers' educators would profit from a systematic diagnostic tool with an established methodology. This article introduces a recent diagnostic method for such purposes that is based on an educational tool called Concept Cartoons. The first part of the article introduces the concept of Concept Cartoons itself, and summarizes our recent research that has employed Concept Cartoons as a qualitative diagnostic tool. It also provides a structured methodology for the diagnostic use, and comments on disadvantages that are closely connected to the nature of the qualitative design. The second part of the article introduces an advanced method that uses a mixed design, i.e. enriches the qualitative results with quantitative characteristics which makes the results more transparent for the user. The mixed method is illustrated through a small empirical study.

\section{CONCEPtual Framework}

\subsection{TEACHERS AND THEIR KNOWLEDGE}

In our study we proceed from the concept of teachers' knowledge in the sense of Shulman (1986), i.e. from the terms of subject matter content knowledge (SMK) and pedagogical content knowledge (PCK). In that sense, we understand the construct of SMK as knowledge of the subject and its organising structures, and PCK as the manner in which teachers relate what they know about teaching to their SMK.

For better clarity of the components of PCK related to our research, we use the categorization of PCK provided by Kleickmann et al. (2013) who distinguish:

- knowledge of pupils (of their strategies, conceptions, and misconceptions, possible difficulties, sources of pupils' misunderstanding, etc.),

- knowledge of tasks (of multiple ways of solving, potential for pupils' learning, etc.),

- knowledge of instruction (of different representations, models, modes of explanation, etc.). 
There is a general consensus that SMK and PCK play a key role in the classroom. They have a significant effect on student mathematics achievement, even in case of primary school classroom and very elementary mathematics content (Hill, Rowan \& Ball, 2005). Mutual relation between SMK and PCK is strongly intertwined: PCK is the one that is more correlated with instructional quality and student progress, and SMK is usually regarded as a necessary but not sufficient prerequisite for the development of PCK (Depaepe, Verschaffel \& Kelchtermans, 2013; Depaepe et al., 2015; Kleickmann et al., 2013). Although the transformation from SMK to PCK is not a unidirectional process, it can be achieved within a suitable learning environment (Kinach, 2002).

\subsection{Concept Cartoons}

An educational tool called Concept Cartoons appeared in Great Britain more than 25 years ago (Keogh \& Naylor, 1993) as a supporting tool for science education at primary and secondary school levels. The authors of the tool elaborated a methodology for the use of the tool in the classroom and created several sets of science Concept Cartoons (e.g. Naylor \& Keogh, 2010). The tool also expanded to other school subjects such as mathematics (Dabell, Keogh \& Naylor, 2008), English language (Turner, Smith, Keogh \& Naylor, 2013), financial education (Jones, Evans \& Storey, 2015).

Concept Cartoons are individual pictures showing a certain situation and several children in a bubble-dialog that comment on the situation. The alternative opinions in bubbles can be correct as well as incorrect, sometimes the correctness is unclear or based on conditions that are not particularly mentioned in the picture. One of the bubbles might contain just a question mark, we call this bubble a blank bubble, to indicate that there might be also other alternative opinions that have not been voiced yet. The recommended order of reading the bubbles is from the top left corner, since additional information on the discussed situation is often presented there. See Fig. 1 for a sample of a Concept Cartoon on a mathematical topic.

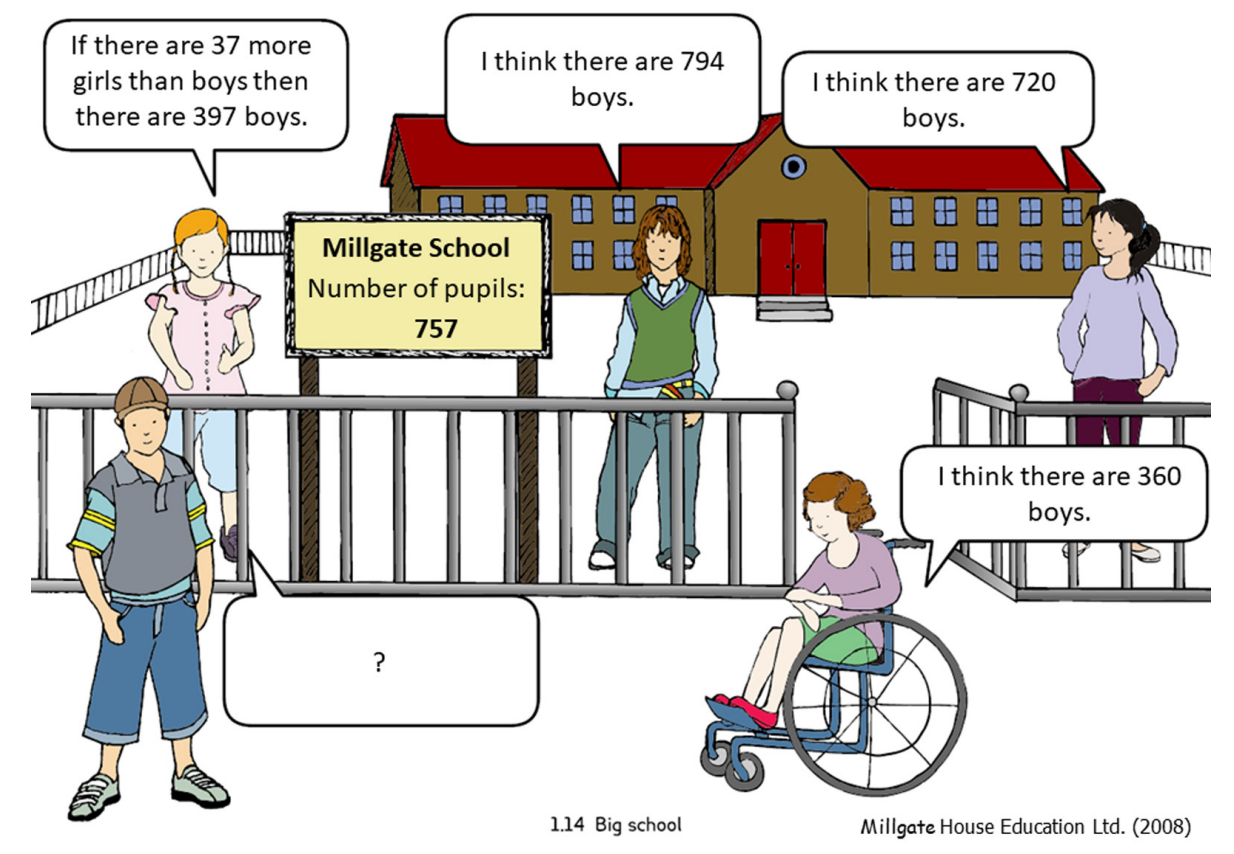

Fig. 1: An original Concept Cartoon with one correct bubble, three incorrect bubbles, and a blank bubble; the picture taken from Dabell et al., 2008: no. 1.14 
When using Concept Cartoons in the classroom, the teacher shows the picture to pupils, invites them to provide their own opinion on the pictured situation, and asks them which children in the picture are right and why. The pupils may work on the task in small groups, or in a whole class discussion. Naylor, Keogh and their colleagues conducted several research studies on this form of use that confirmed the motivational role of the Concept Cartoons tool and showed how the tool could support classroom discussion (Keogh \& Naylor, 1999; Naylor, Keogh \& Downing, 2007).

\subsection{Concept Cartoons diagnostic method}

In this article, we present Concept Cartoons innovatively as a tool for diagnosing SMK and PCK of future primary school teachers. We provide a general methodology for this purpose and illustrate the methodology through a small empirical study. The methodology has been established on the basis of the authors' 7-year experience with Concept Cartoons, repeatedly debugged, and the interim results has been continuously published. Particular references on interim results are continuously given in the text below.

Our method use has two diverse versions, one of them is more focused on SMK while the other on PCK. In both cases, the diagnosed participants (future primary school teachers) are assigned several Concept Cartoons accompanied by a list of indicative questions, just the lists for the two versions differ. Due to the length of the lists, the versions are called a short version, and a long version (see Tab. 1).

Tab. 1: Lists of indicative questions for the short version (left) and for the long version (right)

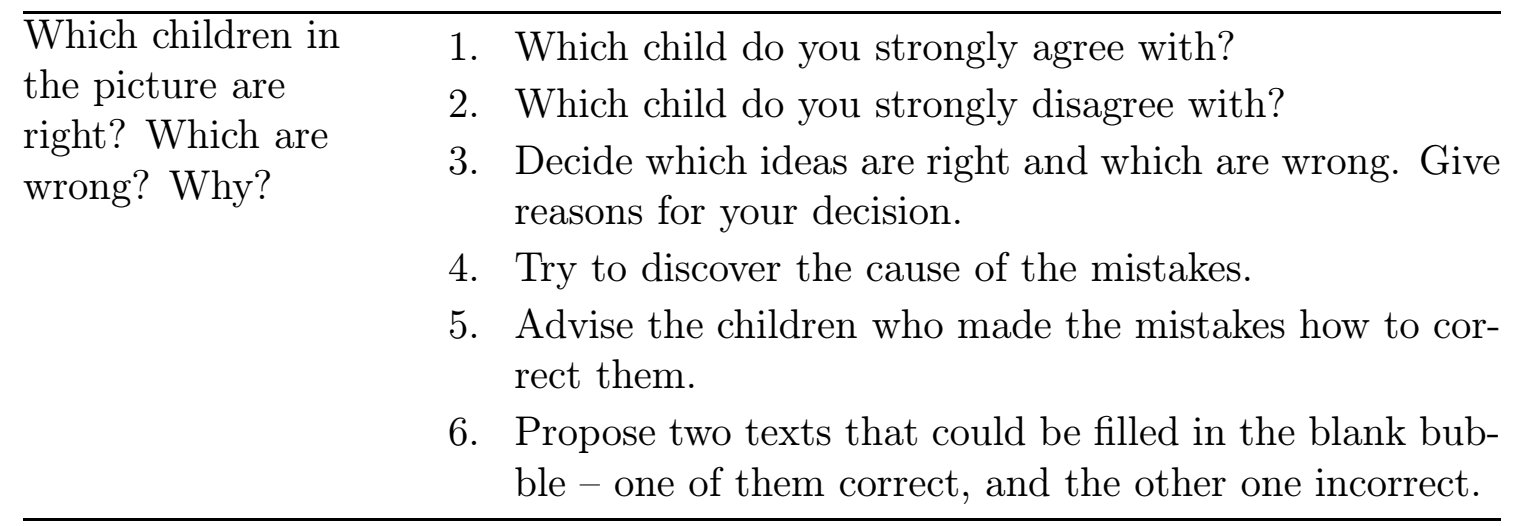

For the diagnostic purposes, each Concept Cartoon is printed on an upper third of an A4 sheet of paper, and the participants are invited to use the rest of the sheet (eventually also the other side of it) to express their responses to the questions. They work individually, ideally in the time span of a two-hour seminar. The time allocation depends on the difficulty of the task behind the Concept Cartoon: in case of the short version, it ranges from 5 to 15 minutes per picture, in case of the long version, it ranges from 20 to 40 minutes per picture. We recommend assigning the Concept Cartoons in sets of 4 or 5 with the short version, and in sets of 2 with the long version. We do not recommend displaying any hurry or announcement in advance of the allocated time, such activities might significantly decrease the amount and quality of collected data. Especially when working with Concept Cartoons for the first time, the participants need enough time to get used to their unusual format and to tune in to the pictured situation. 


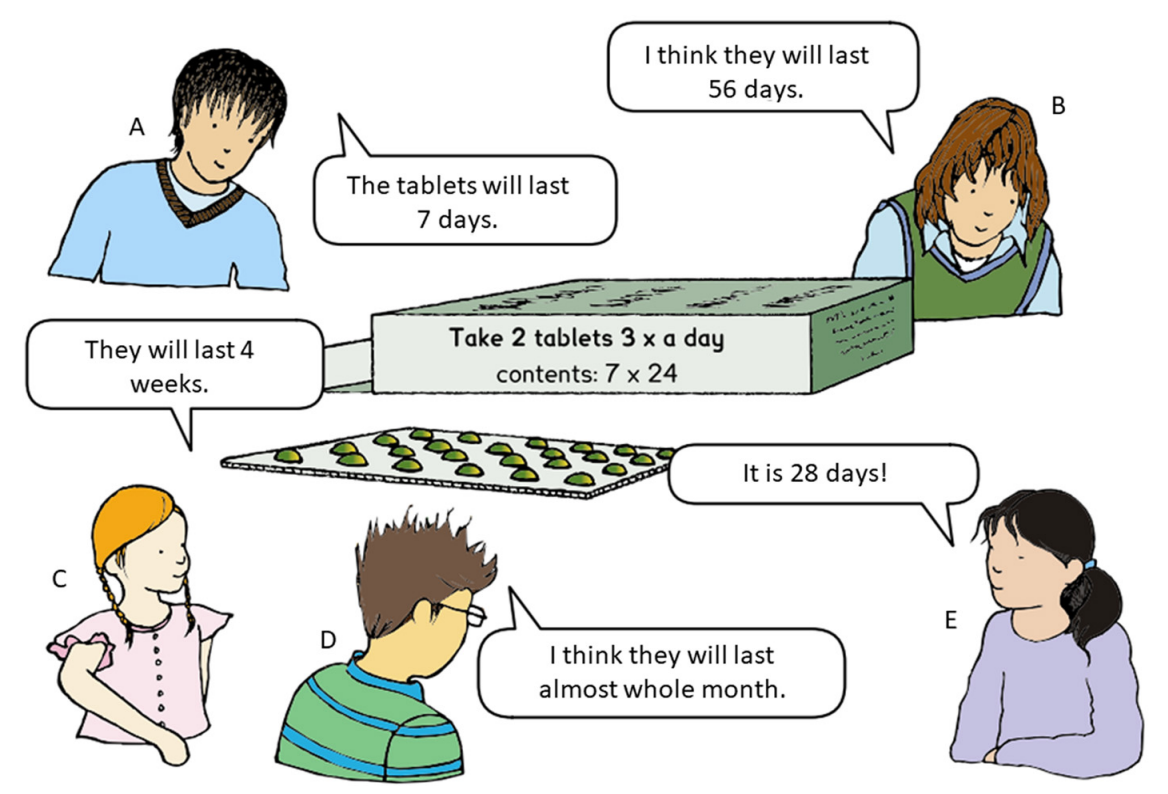

Fig. 2: A Concept Cartoon for the short version, with three correct bubbles, two incorrect bubbles and no blank bubble; the picture modified from Dabell et al., 2008: no. 3.12, the content of two bubbles changed, letters added

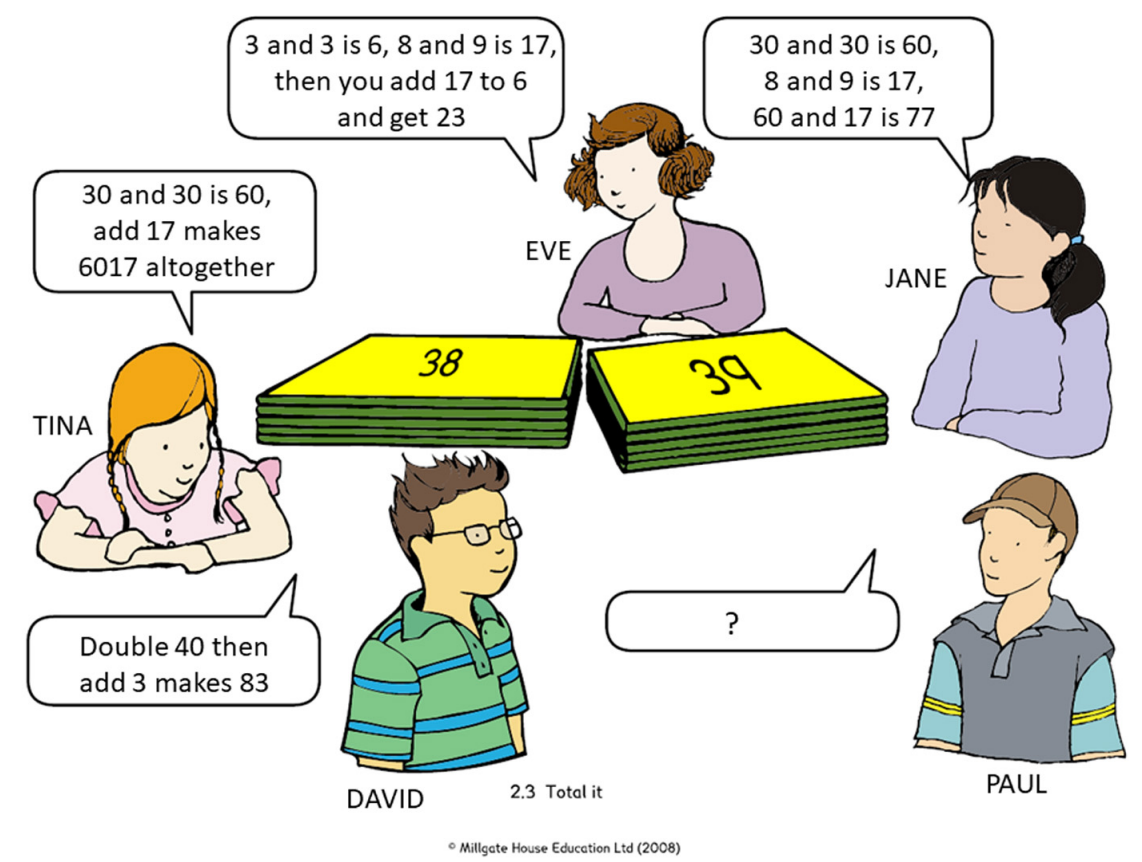

Fig. 3: A Concept Cartoon for the long version; picture taken from Dabell et al. 2008: no. 2.3, names added

For better response, the original format of Concept Cartoons pictures should be additionally supplied with some labels enabling the respondents to distinguish the pictured children when addressing the indicative questions. Such labelling is also useful for the researcher or educator when analysing collected data. As showed in our preparatory study (with 127 future teachers as respondents; see Samková, 2016, $2018 \mathrm{~b}$ ), for the short version it suffices to label the children with letters (A, B, ..., as in Fig. 2). But for the long version, it seems to us that it is better to label the children with names (as in Fig. 3), especially due to the question 5 which might provide better authentic responses when the respondents are able to address the children in the picture personally by calling them by their names. The blank bubble 
is not necessary for the short version but is indispensable for the question 6 of the long version.

As for the mathematical tasks behind the Concept Cartoons, we recommend employing tasks that have one unambiguously interpreted correct solution (e.g. as in Fig. 1) as well as tasks that have more correct solutions or more possible interpretations of a solution (e.g. as in Fig. 2). As for the content of bubbles, we recommend employing bubbles that show only results (e.g. as in Fig. 1, 2) as well as bubbles that show procedures with results (e.g. as in Fig. 3) or procedures without results. Each of the types of tasks and each of the types of bubbles triggers different aspects of knowledge (Samková, 2016, 2018b), and thus a collection with tasks and bubbles of various types allows to reach a wider range of knowledge. Mathematical tasks that are open in the sense of open approach to mathematics (Nohda, 2000) form a natural source of tasks suitable for Concept Cartoons; they allow to discuss various ways of grasping the task, various solution procedures, various solutions, various interpretations of solutions. Even for a task with one unambiguously interpreted correct solution there might exist more solution procedures leading to this solution (e.g. as in Fig. 1).

From the content point of view, the short version method aims mainly at various aspects of SMK such as a proper grasping of the task behind the Concept Cartoon (Samková \& Tichá, 2015), a proper terminology and proper solution procedures (Samková \& Tichá, 2017b; Samková, 2018a), an existence of attempts to seek more than one solution of a task and verify their completeness (Samková \& Tichá, 2016), or skills and abilities to be applied when generalizing (Samková \& Tichá, 2017a).

The diagnostic outcomes on content knowledge obtained through Concept Cartoons are different from results obtained for instance through records of solutions to word problems. This is because the work with Concept Cartoons differs from common problem solving: with Concept Cartoons, the process of solving the problem is not the main goal of the activity. Instead, the participants have to judge various solution procedures or results provided by somebody else, and then they should justify their judgments. Such justifications might fall not only under SMK but also under PCK (particularly under ability to react properly on an opinion of a hypothetical pupil). For the purpose of the justification, the participants may solve the problem themselves and compare their solution(s) with opinions in bubbles, but they may also just verify the opinions in bubbles without solving the problem (e.g. by substituting the unknown quantity in the assignment by a proposed solution, or by rejecting a solution due to obvious incongruity with the conditions of the task; Samková \& Tichá, 2015). Due to this difference between word problems and Concept Cartoons, the Concept Cartoons method can also reveal pieces of SMK that might stay hidden when working with word problems (Samková, 2018a).

The long version method aims mainly on various aspects of PCK such as knowledge of pupils' cognitive processes, knowledge of diverse representations of school mathematics, or ability to react properly on an opinion of a hypothetical pupil. Questions 1 and 2 do not require any justifications and their aim is to focus on spontaneous responses of participants (similarly as in Krauss \& Brunner, 2008; Pankow et al., 2016). Such spontaneous responses form an integral part of PCK, but data related to them are too brief to link them clearly to particular aspects of teacher knowledge. Questions 3 to 6 are based on justifications and explanations, and so the linkage is feasible. Responses to questions 3 to 6 can also reveal how participants reason about a given mathematical topic: what they consider as correct within the topic, how they compose their argumentation, whether they employ procedural or 
conceptual approaches (Samková \& Hošpesová, 2015; Samková, 2016, 2018b), i.e. aspects that fall under SMK.

We have used the above described Concept Cartoons method for several years, with more than 300 future teachers as respondents, and our experience confirmed the motivational nature of the Concept Cartoons tool - we had not had any difficulties with the amount of relevant data provided by the respondents. Similar as the whole-classroom discussion use, obviously also the individual written-form use carries aspects that motivate the respondents to respond to the indicative questions and spend some considerable time in focus on them. That attribute of Concept Cartoons might generally relate to learner's motivation as a consequence of cognitive incongruity (Hatano, 1988) that takes the form of a surprise (when a person meets information that disconfirms their prior knowledge), a perplexity (when a person is aware of equally plausible but competing ideas) or a discoordination (when a person recognizes a lack of coordination among diverse pieces of involved knowledge). At least one of the cognitive incongruity forms is present in a suitably composed Concept Cartoon.

\subsection{EMERGING CONCERNS}

In the references mentioned in the above paragraphs, the short and long versions of the diagnostic method were used separately and independently. Both of the versions were employed there primarily as a qualitative tool, and occasionally supplemented by quantitative diagrams on frequency of certain qualitative aspects (e.g. in Samková \& Tichá, 2017b). The importance of the qualitative type of approach to Concept Cartoons is indisputable, but when working with respondents on a longterm basis or with larger groups of respondents, the qualitative side of the approach exposes its common disadvantages, mainly the inability to overview the results generally, the inability to create brief but concise characteristics of participants, or the inability to rate or order the participants distinctly. We have fought the disadvantages for several years, trying to enhance the qualitative method and ease the disadvantages, and this process has resulted in a decision to enrich the qualitative analysis with a quantitative component regularly, by mixing the qualitative and quantitative approaches. We definitely do not want to depreciate the qualitative component but strengthen it by information that can be supplied just by the quantitative component. This mixed method is described in the following section and illustrated through a small empirical study.

\section{Methodology of The ILlustrative STUDY}

As mentioned above, the study presented in this section serves as an illustration to the mixed diagnostics method. However, we may frame it formally and state its research question as "How may a mixed method approach inform the results of a qualitative Concept Cartoons method for diagnosing subject matter knowledge and pedagogical content knowledge in mathematics?"

\section{$2.1 \quad$ PARTICIPANTS}

In our country, primary school pupils are from 6 to 11 years of age. Primary school teachers are not specialists; they teach all primary school subjects (languages, math- 
ematics, science, arts, physical education, etc.). Those interested in teaching at primary school level have to complete four or five-year undergraduate teacher education program designed especially for future primary school teachers. The primary school curriculum in the Czech Republic consists mainly of arithmetic issues: the concept of natural numbers, the concept of the decimal numeral system, the four operations on natural numbers, the concept of decimal numbers, the concept of positive and negative numbers, and the concept of fractions. The part devoted to geometry covers basic plane and space objects (segment, line, triangle, rectangle, cube, prism, ball), and an introduction to properties of plane objects.

Participants of our research were future primary school teachers - students of five-year undergraduate teacher education program at the Faculty of Education. For our study we choose completely all students from the second study year in the chosen academic year. All of them came to the university directly from the secondary school, just after the state matriculation exam, and without any of their own teaching experiences.

In the beginning, the observed group consisted of 35 future teachers but some of them prematurely terminated or interrupted their studies or absented at certain seminars where data were collected. Due to authenticity reasons, we did not want to acquire data additionally, thus only 23 participants remained for the research.

\subsection{Design OF THE STUDY}

The core of the reported study was to explore SMK and PCK of the participants with the use of the Concept Cartoons method, with an effort to categorize their outcomes systematically. The research was empirical; it proceeded from individual written data collected from the participants within the time span of the given academic year. During the year, the participants attended a mathematics course focusing on arithmetic issues, therefore all collected data were related to arithmetic.

We based the design of the study on mixed approach with concurrent nested design, with priority on qualitative methods (Tashakkori \& Teddlie, 2010). The methodology of the qualitative part of the study was based on substantive coding and constant comparison (Miles, Huberman \& Saldaña, 2014), and the quantitative part of the study used basic descriptive statistics and numerical whole-number scoring.

The aim of the embedded quantitative method was to gain better overall perspective, and so enrich the description of the participants by more transparent characteristics. The integration of qualitative and quantitative data collections took place within the data analysis stage, and within the interpretation stage. During the data analysis stage, SMK data were analysed quantitatively. PCK data were first analysed qualitatively, and then we converted the qualitative themes into numerical scores. During the interpretation phase, we converted the numerical scores related to SMK and PCK to qualitative themes, in order to establish characteristics of the participants.

\subsection{DATA COLLECTION - SMK}

For the purpose of data collection on SMK, the participants underwent a written test consisting of 9 tasks focusing on diverse arithmetic topics related to primary school mathematics; e.g. a task on written subtraction, a task on ordering digital numbers from the smallest, a word problem of application character using division and multiplication of natural numbers, or a task combining data handling with 
establishing difference of integers. We assigned the tasks in the Concept Cartoon form accompanied by the short list of questions, i.e. the participants had to decide which children in the picture are right and which are wrong and justify their decision. Each of the pictures had five bubbles to respond and no blank bubble. One of the test tasks has been shown in Fig. 2.

\subsection{DATA ANALYSis - SMK}

We analysed collected data quantitatively. The participants gained one point for each correct decision that was accompanied by a proper justification, and zero points for incorrect choices or correct choices without proper justification. Since each of the Concept Cartoons in the test contained five bubbles to respond, the maximum possible total per question was five points.

Then we established an SMK test score for each of the participants. This score consisted of the sum of the points for all of the Concept Cartoons in the test. Having 9 tasks in the test with a maximum of five points per each, the maximum possible SMK test score was 45 points.

During the interpretation stage, the SMK scores would transform into final SMK categories.

\subsection{Data COLleCtion - PCK}

Data related to PCK we obtained from participants through 10 Concept Cartoons that were assigned with the long list of questions. The Concept Cartoons focused on diverse arithmetic topics from primary school mathematics: the concept of decimal numeral system, operations on natural and decimal numbers, and the concept of fractions. One of the tasks has been shown in Fig. 3.

Due to unclear linkage to particular knowledge aspects, data obtained as responses to spontaneous questions 1 and 2 were eliminated from the dataset. That means that during data analysis we processed only data obtained as responses to questions 3 to 6 , i.e. questions where the participants had to choose which children in the picture were right and which were wrong and justify their choice, comment on possible sources of mistakes, provide hypothetical children with advice, and propose other alternatives to bubbles.

\subsection{DATA ANALYSIS - PCK}

We processed data from Concept Cartoons qualitatively, started with open coding, paying attention principally to displays related to recognition of right and wrong answers, to recognition of procedures and its particular steps, to identification of the causes of mistakes, to provision of advice, and to provision of alternative ways of solving. However, the process of substantive coding and constant comparison drew our attention also to the mathematical content of particular Concept Cartoons (especially to the difficulty of the discussed tasks), and to the composition of choices proposed in the Concept Cartoons (e.g. to the number of alternatives that could be declared as correct, to the existence or non-existence of bubbles with unclear or conditioned correctness). These factors notably influenced the amount and quality of relevant data provided by the participants to individual Concept Cartoons and thwarted any efforts toward a systematic common approach to data. 
Thus we sorted the Concept Cartoons according to the composition and task difficulty, focused on Concept Cartoons with the highest density of relevant data related to PCK, and selected two representative Concept Cartoons with a similar composition but diverse difficulty. The less difficult task (labelled as easy; has been shown in Fig. 3) concentrated on natural numbers, the more difficult one (labelled as non-easy; see Fig. 4) concentrated on fractions. Each of them had one correct bubble and three incorrect bubbles, the (in)correctness being unambiguous for all bubbles. The incorrect bubbles presented common misconceptions on the discussed topics.

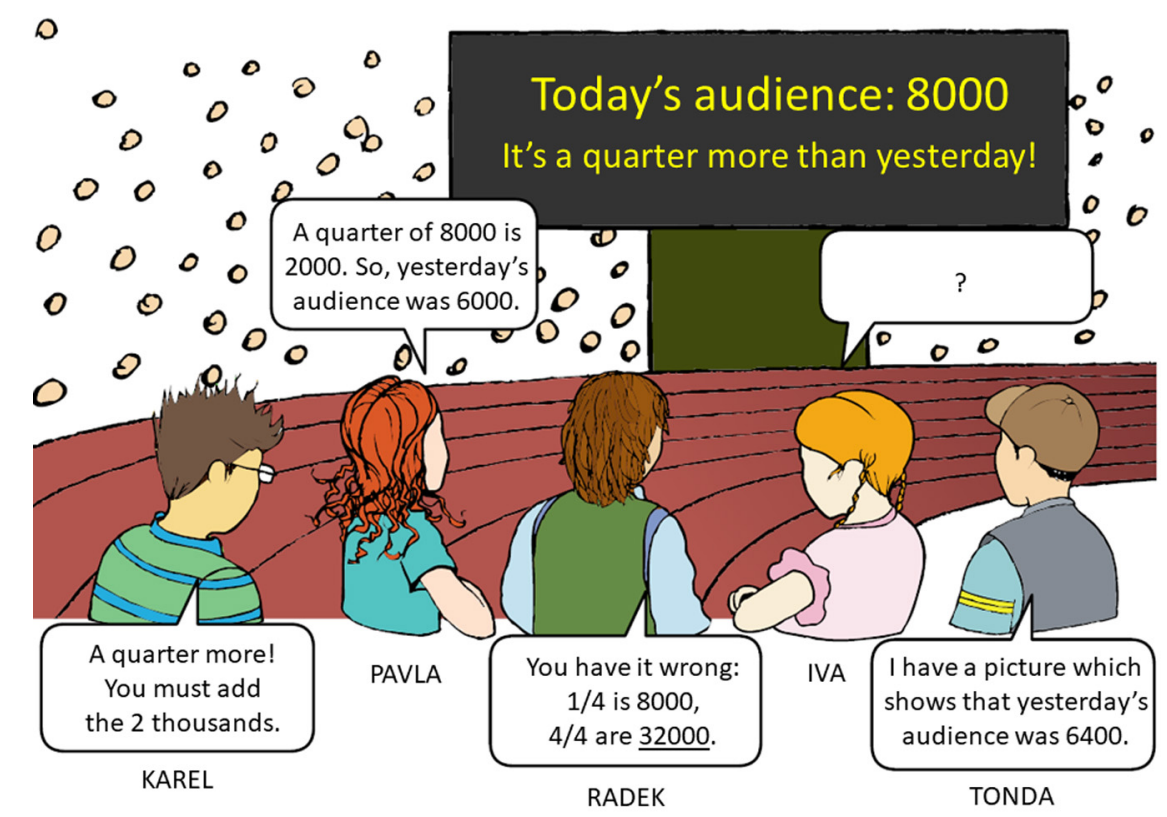

Fig. 4: The Concept Cartoon labelled as non-easy one; template with empty bubbles and empty notice board taken from Dabell et al. 2008: no. 2.16, names added

With the two representative Concept Cartoons and the codes obtained for them previously, we continued the process of data analysis by other substantive coding and constant comparison. Afterwards, we related each of the relevant PCK codes to one of the three PCK categories provided by Kleickmann et al. (2013): knowledge of pupils, knowledge of tasks, and knowledge of instruction.

For the purpose of converting the qualitative themes into numerical scores, we scored the codes by

- one positive point for each occurrence if the code addressed a display of good PCK (e.g. correct explanation, didactically appropriate advice, ability to identify a common misconception, suggestion of a plausible misconception into a blank bubble), or

- one negative point if the code addressed a display of weak PCK (e.g. wrong explanation, didactically inappropriate advice, inability to identify a common misconception, suggestion of an unrealistic misconception into a blank bubble).

For each of the participants and each of the two selected tasks, we established a sum of the scores for each of the PCK categories, and named these sums as task score, pupil score, and instruction score. Then we named the sum of task, pupil and instruction scores related to the easier task as a PCK easy task score, and the sum of task, pupil and instruction scores related to the more difficult task as a $P C K$ non-easy task score. During the interpretation stage, the relations between the PCK 

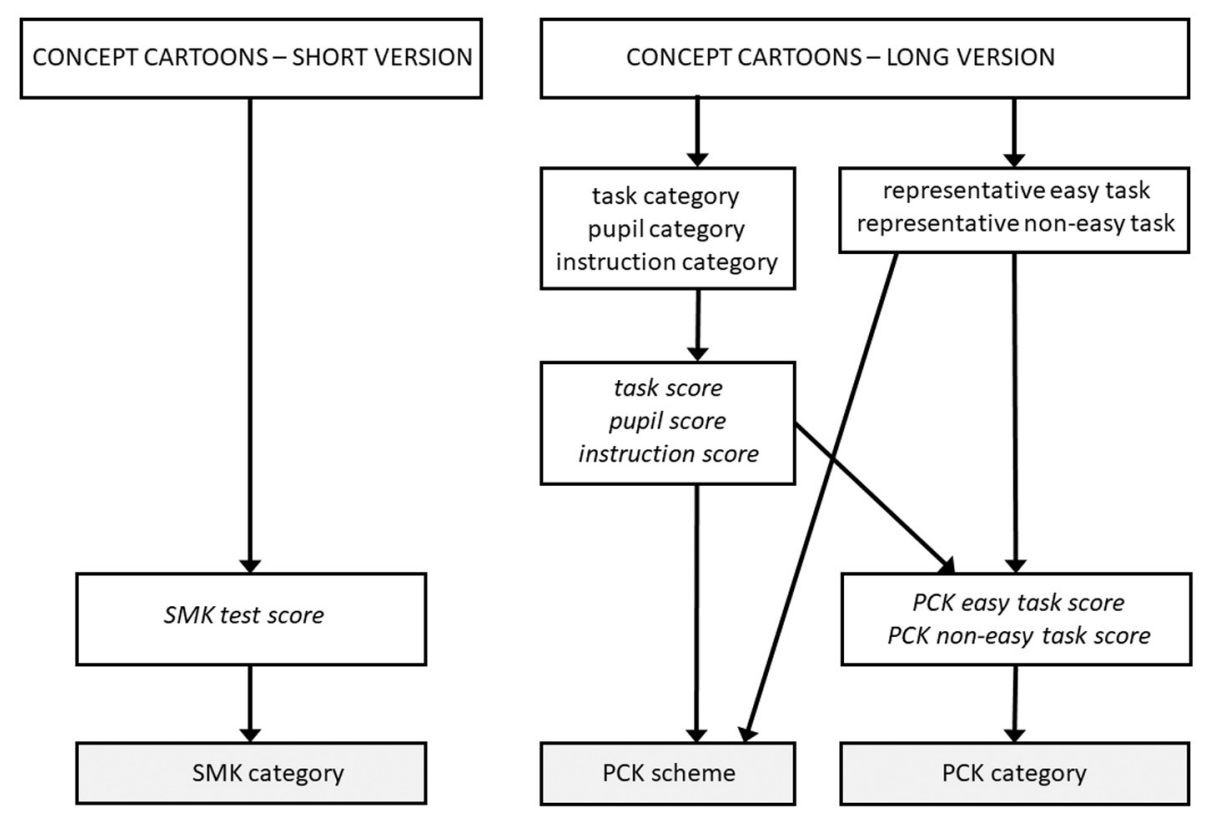

Fig. 5: A scheme of handling SMK and PCK data; data sources are written in capitals, outcomes of qualitative approach in roman, and outcomes of quantitative approach in italics, final outcomes are shaded

scores would transform into characteristics (illustrative schemes) and into final PCK categories.

For a detailed scheme on data handling see Fig. 5.

\subsection{REMARK ON PARTIAL INTERCONNECTION OF PCK DATA}

Eight of the 10 Concept Cartoons from sections 2.5 and 2.6 were also used as an instrument for data collection in two former explorative studies focusing on possible usage of Concept Cartoons in purely qualitative diagnosis of pedagogical content knowledge in mathematics (Samková, 2016, 2018b). The first of the explorative studies was reported in the Czech language, the second one in English. Both of them widely presented the process of the qualitative analysis and its results and illustrated them by multiple data excerpts related to two chosen Concept Cartoons. These illustrative Concept Cartoons appeared to be the same as the two Cartoons selected as representative in the section 2.6 of this study. Since the two explorative studies also proceeded from the same group of participants as the study presented here (just 6 of the original participants absented at seminars where SMK data were collected and thus were removed from the current dataset) and the code numbers of participants stayed the same, it is possible to seek the two studies for illustrative data excerpts and more details on particular PCK codes. However, the current study uses from the two former studies only the part of raw data related to the 8 common Concept Cartoons and the interim results of the open coding process that was applied on it.

\section{Results}

\subsection{CharaCteristics ON SMK}

Data analysis related to SMK showed that the arithmetic mean of the SMK test scores of all the participants equalled 30.96 points, the worst participant obtained 20 points, and the best participant achieved all 45 points. 
According to the scores, we distributed the participants among three final SMK categories:

- good SMK (more than 32 points; 7 participants),

- average $S M K$ (30 to 32 points; 9 participants), and

- weak $S M K$ (less than 30 points; 7 participants).

\subsection{INDIVIDUAL COMPARATIVE SCHEMES ON PCK}

Data analysis related to PCK showed that some of the participants expressed good PCK related to knowledge of tasks (e.g. when they were able to recognize various alternative correct ways of solving a task), knowledge of pupils (e.g. when they were able to identify various pupils' misconceptions), and also to knowledge of instruction (e.g. when they were able to provide the child with a constructive explanation). On the other hand, some of the participants expressed weak knowledge of tasks (e.g. when they were not able to recognize a correct way of solving a task), weak knowledge of pupils (e.g. when they were not able to identify common pupils' misconceptions) or weak knowledge of instruction (e.g. when they provided the child with a wrong explanation).

Based on data from the two selected Concept Cartoons, we established a schema for each of the participants to illustrate their PCK. The schema was comparative; it compared the task score related to the easy task with the task score related to the non-easy task, the pupil score related to the easy task with the pupil score related to the non-easy task, and the instruction score related to the easy task with the instruction score related to the non-easy task. For samples of schemes see Fig. 6.
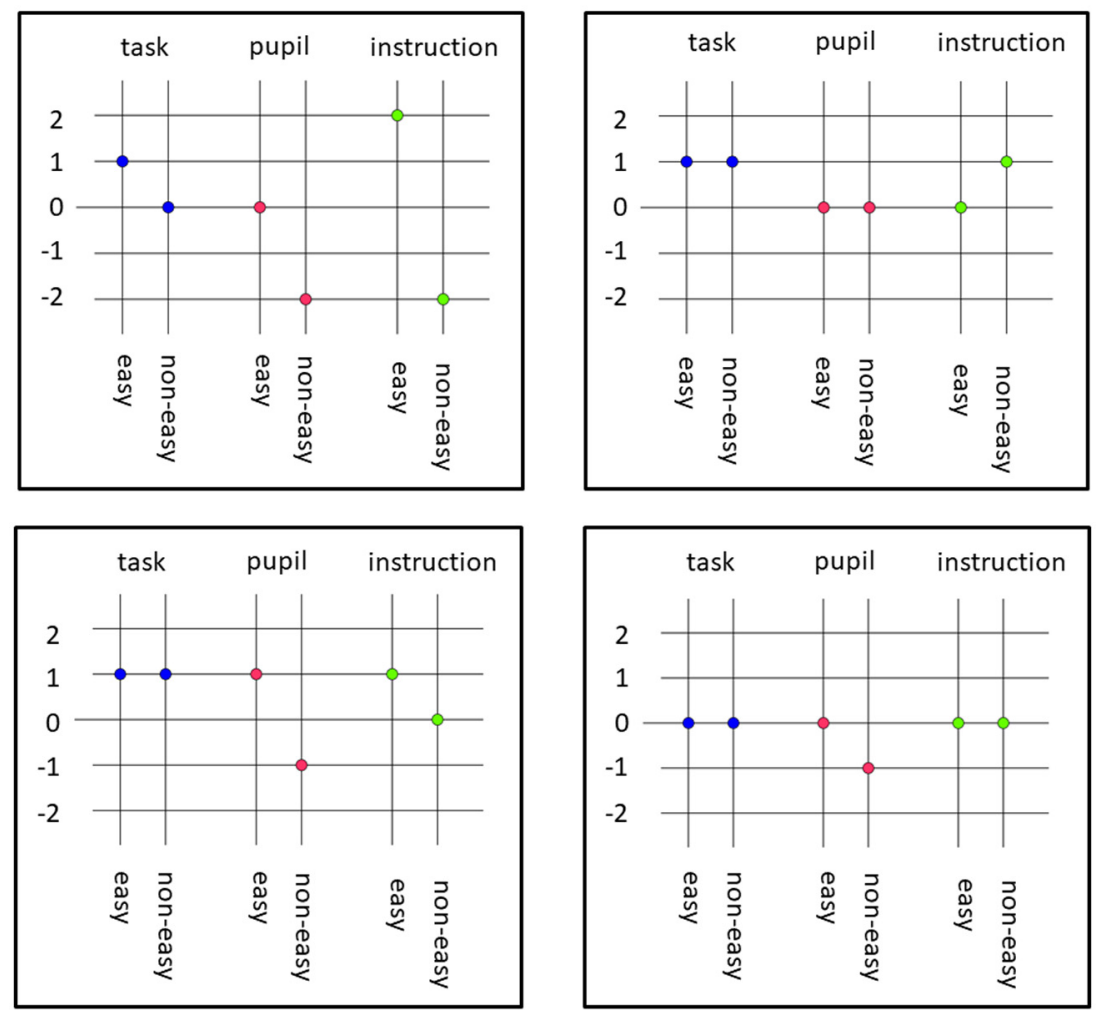

Fig. 6: Comparative PCK schemes of four of the participants (top left: S16, top right: S32, bottom left: S5, bottom right: S11) 


\subsection{Characteristics ON PCK}

Numerically, the data analysis showed that the arithmetic mean of the PCK easy task scores of all the participants equalled 1.26 points, the worst participant scored -3 points, and the best participant scored 4 points. The arithmetic mean of the PCK non-easy task scores of all the participants equalled 0.74 points, the worst participant scored -4 points, and the best participant scored 5 points.

The scores for individual participants could also be found in their comparative schemes. As for the four participants from Fig. 6:

- S16 had the PCK easy task score of $1+0+2=3$ points and the PCK non-easy task score of $0+(-2)+(-2)=-4$ points,

- S32 had the PCK easy task score of $1+0+0=1$ point and the PCK non-easy task score of $1+0+1=2$ points,

- S5 had the PCK easy task score of $1+1+1=3$ points and the PCK non-easy task score of $1+(-1)+0=0$ points,

- S11 had the PCK easy task score of $0+0+0=0$ points and the PCK non-easy task score of $0+(-1)+0=-1$ point.

According to the scores, participants were of three types: those who had both the PCK easy topic score and the PCK non-easy task score positive (e.g. S32), those who had the PCK easy topic score positive but the PCK non-easy task score non-positive (e.g. S16, S5), and those who had both the PCK easy topic score and the PCK non-easy task score non-positive (e.g. S11). These three types established our final qualitative PCK categories: we labelled

- participants with both the scores being positive as having good PCK (10 participants),

- participants with the first score being positive and the second non-positive as having ordinary PCK (6 participants), and

- participants with both the scores being non-positive as having weak PCK (7 participants).

\subsection{SMK VS PCK CHARACTERISTICS}

Having the final SMK and PCK categories for each of the participants, we observed how the two categories varied for individual participants. There were 8 diverse combinations, some of them indicating similar levels of SMK and PCK (e.g. good SMK with good PCK, average SMK with ordinary PCK), but the others not (e.g. good SMK with ordinary PCK, weak SMK with good PCK). See Tab. 2 for the list of combinations and their frequency.

Tab. 2: Numbers of participants that displayed particular combinations of SMK and PCK final categories

\begin{tabular}{lccc}
\hline & good PCK & ordinary PCK & weak PCK \\
\hline good SMK & 5 & 2 & 0 \\
\hline average SMK & 3 & 2 & 4 \\
\hline weak SMK & 2 & 2 & 3 \\
\hline
\end{tabular}

As for the four participants from Fig. 6:

- S16 had average SMK (her SMK test score was 32 points) and ordinary PCK;

- S32 had weak SMK (her SMK test score was 28 points) but good PCK; 
- S5 had good SMK (her SMK test score was the maximal one of 45 points) but ordinary PCK;

- S11 had weak SMK (her SMK test score was 23 points) and weak PCK.

\section{Discussion}

This contribution aimed to present a diagnostic Concept Cartoons method in all its existing forms (short, long; qualitative, mixed), and illustrate the newest form (i.e. the mixed one) through an illustrative empirical study. As an answer to the research question: "How may a mixed method approach inform the results of a qualitative Concept Cartoons method for diagnosing subject matter knowledge and pedagogical content knowledge in mathematics?" we may state that the quantitative component can provide us with an easy way to overview concise characteristics and comparative diagrams, and enable us to create some more general categories to sort the diagnosed participants distinctly. With the emphasis still on the qualitative aspects, the mixed design may facilitate organization of a researcher's work when facing long-term diagnostics matters or diagnostics matters with larger groups of respondents. From the perspective of educators of future teachers, the mixed design may facilitate their educational work by making the actual qualitative characteristics of teacher knowledge more transparent. The proposed mixed design may also draw attention on unusual relations in data, as commented in detail in the following paragraph.

The results of the study indirectly revealed mutual relations between SMK and PCK (referred e.g. by Depaepe et al., 2013). In particular, the combinations of SMK and PCK categories of the participants S11 (weak SMK vs weak PCK) and S5 (good SMK with the best possible test score vs ordinary PCK) distinctly confirm the often voiced statement that SMK is necessary but not sufficient prerequisite for PCK. However, the combination of SMK and PCK categories of the participant S32 (weak SMK vs good PCK) leads us to question the exact meaning of the word "necessary" in the statement. Do these findings mean that SMK and PCK are partially independent? This is the way how the results of the mixed design research might be used in qualitative diagnostics: having results from the mixed study that point out interesting or unexpected relations of two distinct overview characteristics, we may return back to raw data and purely qualitative design to inquire in detail the aspect and relations that led to the two characteristics. In this particular case, raw data provided by the participant S32 showed that the combination of weak SMK and good PCK categories was actually caused by mistakes in SMK tasks based on calculation algorithms and data handling (i.e. in types of tasks that were not chosen as representative in the PCK part of mixed design analysis), and by missing justifications to some of the correct decisions.

To address further the question of the word "necessary" in the statement about PCK and SMK, we may revert to a subsequent empirical study (Samková, 2018a) where the respondents first solved a word problem with similar mathematical background as the task in Fig. 4, and then the Concept Cartoon from Fig. 4. Some of the respondents solved the word problem incorrectly (which is a display of weak SMK) but decided about the Concept Cartoon correctly, through a verification of all individual results proposed in bubbles (which is a display of good PCK - a proper response to an opinion of a hypothetical pupil, but also a display of good SMK just of a different type than with the word problem). 
From the perspective of the participants of the study, the future primary school teachers, the Concept Cartoons diagnostic method has a multiple role in their professional preparation: among others, just the attendance in the diagnostic process may train the future teachers indirectly and continuously in their awareness of potential pupils' reasoning that might appear in the classroom in their future teaching practice. It relates the Concept Cartoons method to teachers' professional vision, knowledge-based reasoning and noticing (van Es \& Sherin, 2008) that are usually supported through observing and discussing video recordings of teaching practice (Stockero, Rupnow \& Pascoe, 2017). In contrast with these video-based approaches, Concept Cartoons do not require any video equipment nor informed consents of the pictured children. Concept Cartoons are not alone in such independence - there are other picture-based formats focusing on enhancement of SMK and PCK of future teachers and teachers. For instance, sequential pictorial simulations that focus on the consequences of different teacher behaviour in one particular classroom situation (Webel, Conner \& Zhao, 2018), or text-based or picture-based simulated records of teacher-pupil interactions called vignettes that focus on a proper use of multiple representations in the classroom (Friesen \& Kuntze, 2018).

From the diagnostic perspective, the diagnostic methods used for SMK and PCK are often conducted either qualitatively, or quantitatively (Depaepe et al., 2013). Sometimes the diagnostic instruments are divided into two parts, one of them being analysed qualitatively, and the other quantitatively, e.g. as with vignettes (Friesen \& Kuntze, 2018) that have the qualitative part based on written narratives, and the quantitative part based on a Likert scale. The mixed design appears rarely, usually in relation to computer supported knowledge diagnostics (Yankovskaya, Dementyev \& Yamshanov, 2015). As for the Concept Cartoons, our diagnostic approach to this tool is unique, there are no other similar formats focusing both on SMK and PCK of future teachers and teachers there.

From the perspective of particular tasks employed in this study, the two Concept Cartoons with the highest density of relevant PCK data (which resulted in handling them as representative), are both of discursive nature. Moreover, both of them address the issue of the role of language in mathematics, each of them from a different point of view. The Concept Cartoon from Fig. 3 contributes to the question of demarcation between the classroom use of informal everyday language and mathematical language, since Tina employs there an inappropriate everyday meaning of the word "add" in a mathematical situation related to the operation of addition. On the other hand, the Concept Cartoon from Fig. 4 is based on a mathematical task that is difficult due to implicit mathematical relations hidden in the syntax of the assignment: one has to know that in such a situation, the reference to the whole is always hidden in the text immediately after the word "than" (in the Czech language, the syntax in this case is the same as in English). The future teachers are not often aware of this hidden reference themselves, some of them even tend to declare such tasks as ambiguous since the whole is not clearly given in the assignment (Samková \& Tichá, 2017b). Thus, both the Concept Cartoons provide an illustration of the fact that linguistic challenges need to be addressed in the mathematics classroom in order to construct mathematical knowledge properly (Schleppegrell, 2007).

Last but not least, we have to emphasize that the results obtained from the mixed method are heavily based on qualitative data and thus have to be carefully handled and interpreted as if qualitative: the categories obtained do not have any absolute value, their meaning is closely related to the particular set of tasks, particular group of participants and particular person that provided data analysis. However, the 
course of the mixed study can be applied to diverse sets of tasks and diverse groups of participants, in that sense is the reported method universal.

We hope that the Concept Cartoons diagnostic method described in this article could find its way to other teachers' educators and enrich the professional preparation of future teachers at other faculties, in other countries, in education of other school subjects. The tasks behind Concept Cartoons and the content of the bubbles may easily be adjusted to diverse cultural and educational context, thus Concept Cartoons could reflect diverse classroom realities.

\section{REFERENCES}

Dabell, J., Keogh, B. \& Naylor, S. (2008). Concept Cartoons in Mathematics Education. Sandbach: Millgate House Education.

Depaepe, F., Torbeyns, J., Vermeersch, N., Janssens, D., Janssen, R., Kelchtermans, G., Verschaffel, L. \& Van Dooren, W. (2015). Teachers' content and pedagogical content knowledge on rational numbers: a comparison of prospective elementary and lower secondary school teachers. Teaching and Teacher Education, 47, 82-92. https://doi.org/10.1016/j.tate.2014.12.009

Depaepe, F., Verschaffel, L. \& Kelchtermans, G. (2013). Pedagogical content knowledge: A systematic review of the way in which the concept has pervaded mathematics educational research. Teaching and Teacher Education, 34, 12-25. https://doi.org/10.1016/j.tate.2013.03.001

Friesen, M. \& Kuntze, S. (2018). Competence assessment with representations of practice in text, comic and video format. In O. Buchbinder \& S. Kuntze (Eds.), Mathematics Teachers Engaging with Representations of Practice (113-130). Cham: Springer. https://doi.org/10.1007/978-3-319-70594-1_7

Hatano, G. (1988). Social and motivational bases for mathematical understanding. In G. B. Saxe \& M. Gearhart (Eds.), Children's Mathematics. New Directions for Child Development (55-70). San Francisco: Jossey-Bass. https://doi.org/10.1002/cd.23219884105

Hill, H. C., Rowan, B. \& Ball, D. L. (2005). Effects of teachers' mathematical knowledge for teaching on student achievement. American Educational Research Journal, 42(1), 371-406. https://doi.org/10.3102/00028312042002371

Jones, A., Evans, D. \& Storey, P. (2015). Financial Skills Concept Cartoons. Sandbach: Millgate House Publishers.

Keogh, B. \& Naylor, S. (1993). Learning in science: another way in. Primary Science Review, 26(2), 22-23.

Keogh, B. \& Naylor, S. (1999). Concept cartoons, teaching and learning in science: an evaluation. International Journal of Science Education, 21(4), 431-446.

https://doi.org/10.1080/095006999290642

Kinach, B. M. (2002). A cognitive strategy for developing pedagogical content knowledge in secondary mathematics methods course: toward a model of effective practice. Teaching and Teacher Education, 18, 51-71. https://doi.org/10.1016/s0742-051x(01)00050-6

Kleickmann, T., Richter, D., Kunter, M., Elsner, J., Besser, M., Krauss, S. \& Baumert, J. (2013). Teachers' content and pedagogical content knowledge: the role of 
structural differences in teacher education. Journal of Teacher Education, 64(1), 90-106. https://doi.org/10.1177/0022487112460398

Krauss, S. \& Brunner, M. (2008). Professionelles Reagieren auf Schülerantworten: Ein Reaktionszeittest für Mathematiklehrkräfte. In E. Vásárhelyi (Ed.), Beiträge zum Mathematikunterricht 2008. Vorträge auf der 42. Tagung für Didaktik der Mathematik vom 13. 3. bis 18. 3. 2007 in Budapest (400-403). Münster: WTM-Verlag.

Miles, M. B., Huberman, A. M. \& Saldaña, J. (2014). Qualitative data analysis. A methods sourcebook. Thousand Oaks, CA: SAGE.

Naylor, S. \& Keogh, B. (2010). Concept Cartoons in Science Education, $2^{\text {nd }}$ Edition. Sandbach: Millgate House Education.

Naylor, S., Keogh, B. \& Downing, B. (2007). Argumentation and primary science. Research in Science Education, 37, 17-39. https://doi.org/10.1007/s11165-005-9002-5

Nohda, N. (2000). Teaching by open-approach method in Japanese mathematics classroom. In T. Nakahara \& M. Koyama (Eds.), Proceedings of PME 24 (Vol. 1) (39-53). Hiroshima: Hiroshima University.

Pankow, L., Kaiser, G., Busse, A., König, J., Blömeke, S., Hoth, J. \& Döhrmann, M. (2016). Early career teachers' ability to focus on typical students errors in relation to the complexity of mathematical topic. ZDM, 48(1-2), 55-67.

https://doi.org/10.1007/s11858-016-0763-2

Samková, L. (2016). Didaktické znalosti obsahu budoucích učitelů 1. stupně základní školy před studiem didaktiky matematiky. Scientia in educatione, 7(2), 71-99.

Samková, L. (2018a). Assessing future teachers' knowledge on fractions: written tests vs Concept Cartoons. Journal on Efficiency and Responsibility in Education and Science, 11(3), 45-52. https://doi.org/10.7160/eriesj.2018.110301

Samková, L. (2018b). Concept Cartoons as a representation of practice. In O. Buchbinder \& S. Kuntze (Eds.), Mathematics Teachers Engaging with Representations of Practice (71-93). Cham: Springer. https://doi.org/10.1007/978-3-319-70594-1_5

Samková, L. \& Hošpesová, A. (2015). Using Concept Cartoons to investigate future teachers' knowledge. In K. Krainer \& N. Vondrová (Eds.), Proceedings of CERME 9 (3241-3247). Praha: Univerzita Karlova, Pedagogická fakulta.

Samková, L. \& Tichá, M. (2015). Investigating future primary teachers' grasping of situations related to unequal partition word problems. In C. Sabena \& B. Di Paola (Eds.), Quaderni di Ricerca in Didattica (Mathematics), n. 25, Supplemento n. 2. Proceedings CIEAEM 67, Teaching and learning mathematics: resources and obstacles (295-303). Palermo, Italy: G.R.I.M.

Samková, L. \& Tichá, M. (2016). On the way to develop open approach to mathematics in future primary school teachers. Journal on Efficiency and Responsibility in Education and Science, 9(2), 37-44. https://doi.org/10.7160/eriesj.2016.090202

Samková, L. \& Tichá, M. (2017a). Observing how future primary school teachers reason and generalize: the case of number triangles and Concept Cartoons. In D. Szarková et al. (Eds.), Proceedings of Aplimat 2017 (1354-1368). Bratislava: STU.

Samková, L. \& Tichá, M. (2017b). On the way to observe how future primary school teachers reason about fractions. Journal on Efficiency and Responsibility in Education and Science, 10(4), 93-100. https://doi.org/10.7160/eriesj.2017.100401 
Schleppegrell, M. J. (2007). The linguistic challenges of mathematics teaching and learning: a research review. Reading \& Writing Quarterly: Overcoming Learning Difficulties, 23(2), 139-159. https://doi.org/10.1080/10573560601158461

Shulman, L. S. (1986). Those who understand: knowledge growth in teaching. Educational Researcher, 15(2), 4-14. https://doi.org/10.2307/1175860

Stockero, S. L., Rupnow, R. L. \& Pascoe, A. E. (2017). Learning to notice important student mathematical thinking in complex classroom interactions. Teaching and Teacher Education, 63, 384-395. https://doi.org/10.1016/j.tate.2017.01.006

Tashakkori, A. \& Teddlie, C. (Eds.). (2010). Handbook of mixed methods in social $\&$ behavioral research. Thousand Oaks: SAGE. https://doi.org/10.4135/9781506335193

Turner, J., Smith, C., Keogh, B. \& Naylor, S. (2013). English Concept Cartoons.

Sandbach: Millgate House Publishers.

van Es, E. A. \& Sherin, M. G. (2008). Mathematics teachers' "learning to notice" in the context of a video club. Teaching and Teacher Education, 24(2), 244-276.

https://doi.org/10.1016/j.tate.2006.11.005

Webel, C., Conner, K. \& Zhao, W. (2018). Simulations as a tool for practicing questioning. In O. Buchbinder \& S. Kuntze (Eds.), Mathematics Teachers Engaging with Representations of Practice (95-112). Cham: Springer.

https://doi.org/10.1007/978-3-319-70594-1_6

Yankovskaya, A., Dementyev, Y. \& Yamshanov, A. (2015). Application of learning and testing intelligent system with cognitive component based on mixed diagnostics tests. Procedia - Social and Behavioral Sciences, 206, 254-261.

https://doi.org/10.1016/j.sbspro.2015.10.019

LiBUŠE SAMKOVÁ, lsamkova@pf.jcu.cz

University of South Bohemia

Faculty of Education

Jeronýmova 10, 37115 Ceské Budějovice, Czech Republic 